\title{
Phylogeny and S1 Gene Variation of Infectious Bronchitis Virus Detected in Broilers and Layers in Turkey
}

\author{
Huseyin Yilmaz, ${ }^{\mathrm{AH}}$ Eda Altan, ${ }^{\mathrm{A}}$ Utku Y. Cizmecigil, ${ }^{\mathrm{A}}$ Aydin Gurel, ${ }^{\mathrm{B}}$ Gulay Yuzbasioglu Ozturk, ${ }^{\mathrm{B}}$ Ozge Erdogan Bamac, ${ }^{\mathrm{B}}$ \\ Ozge Aydin, ${ }^{\mathrm{A}}$ Paul Britton, ${ }^{\mathrm{C}}$ Isabella Monne, ${ }^{\mathrm{D}}$ Burhan Cetinkaya,${ }^{\mathrm{E}}$ Kenton L. Morgan, ${ }^{\mathrm{F}}$ Bonto Faburay, ${ }^{\mathrm{G}}$ Juergen A. Richt, ${ }^{\mathrm{G}}$ \\ and Nuri Turan ${ }^{\mathrm{A}}$

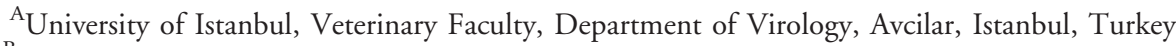 \\ ${ }^{B}$ University of Istanbul, Veterinary Faculty, Department of Pathology, Avcilar, Istanbul, Turkey \\ Cirbright Institute, Compton Laboratory, Compton, Newbury, Berkshire, RG20 7NN, UK \\ ${ }^{D}$ Division of Comparative Biomedical Sciences, OIE/FAO and Istituto Zooprofilattico, Sperimentale delle Venezie, Viale dell'Università, 10, \\ 35020, Legnaro (Padova), Italy \\ ${ }^{\mathrm{E}}$ University of Firat, Veterinary Faculty, Department of Microbiology, Elazig, Turkey \\ ${ }^{\mathrm{F}}$ Institute of Ageing and Chronic Disease and School of Veterinary Science, University of Liverpool, Leahurst, Neston, CH64 7TE, UK \\ ${ }^{\mathrm{G}}$ Department of Diagnostic Medicine and Pathobiology, College of Veterinary Medicine, Kansas State University, 1800 Denison Avenue, \\ Manhattan, KS 66506
}

Received 11 December 2015; Accepted 30 March 2016; Published ahead of print 14 April 2016

SUMMARY. The avian coronavirus infectious bronchitis virus (AvCoV-IBV) is recognized as an important global pathogen because new variants are a continuous threat to the poultry industry worldwide. This study investigates the genetic origin and diversity of AvCoV-IBV by analysis of the S1 sequence derived from 49 broiler flocks and 14 layer flocks in different regions of Turkey. AvCoV-IBV RNA was detected in 41 (83.6\%) broiler flocks and nine (64.2\%) of the layer flocks by TaqMan real-time RT-PCR. In addition, AvCoV-IBV RNA was detected in the tracheas 27/30 (90\%), lungs 31/49 (62.2\%), caecal tonsils 7/22 $(31.8 \%)$, and kidneys $4 / 49$ (8.1\%) of broiler flocks examined. Pathologic lesions, hemorrhages, and mononuclear infiltrations were predominantly observed in tracheas and to a lesser extent in the lungs and a few in kidneys. A phylogenetic tree based on partial S1 sequences of the detected AvCoV-IBVs (including isolates) revealed that 1) viruses detected in five broiler flocks were similar to the IBV vaccines Ma5, H120, M41; 2) viruses detected in 24 broiler flocks were similar to those previously reported from Turkey and to Israel variant-2 strains; 3) viruses detected in seven layer flocks were different from those found in any of the broiler flocks but similar to viruses previously reported from Iran, India, and China (similar to Israel variant-1 and 4/91 serotypes); and 4) that the AVCoV-IBV, Israeli variant-2 strain, found to be circulating in Turkey appears to be undergoing molecular evolution. In conclusion, genetically different AvCoV-IBV strains, including vaccine-like strains, based on their partial S1 sequence, are circulating in broiler and layer chicken flocks in Turkey and the Israeli variant- 2 strain is undergoing evolution.

RESUMEN. Análisis filogenético y variación del gene S1 de virus de la bronquitis infecciosa detectados en pollos y gallinas de postura en Turquía.

El coronavirus aviar conocido como el virus de la bronquitis infecciosa aviar (AvCoV-IBV), es reconocido como un patógeno global importante debido a que las nuevas variantes son una amenaza continua para la industria avícola en todo el mundo. En este estudio se investigó el origen genético y la diversidad de los virus de bronquitis de bronquitis mediante el análisis de la secuencia del gene S1 de virus derivados de 49 lotes de pollos y de14 lotes de ponedoras en diferentes regiones de Turquía. Se detectó ARN del virus de la bronquitis infecciosa en $41(83.6 \%)$ lotes de pollos y en nueve (64.2\%) de los lotes de ponedoras por un método de transcripción reversa y PCR en tiempo con sondas TaqMan. Además, se detectó ARN de virus de la bronquitis infecciosa en las tráqueas 27/30 (90\%), los pulmones $31 / 49(62.2 \%)$, las tonsilas cecales $7 / 22(31.8 \%)$, y riñones $4 / 49(8.1 \%)$ de las parvadas de pollo de engorde examinadas. Se observaron lesiones patológicas, hemorragias, e infiltraciones mononucleares principalmente en las tráqueas, en menor medida en los pulmones y en algunos riñones. Un árbol filogenético basado en las secuencias parciales del gene S1 de los virus de la bronquitis detectados (incluyendo aislamientos) reveló que 1) los virus detectados en cinco lotes de pollos fueron similares a las vacunas Ma5, H120, M41; 2) los virus detectados en 24 lotes de pollos fueron similares a los virus previamente reportados en Turquía y a las cepas variantes 2 de Israel; 3 ) los virus detectados en siete parvadas de gallinas de postura fueron diferentes de los virus que se detectaron en todas las parvadas de pollos de engorde, pero similares a los virus que se habían reportado en Irán, India y China (similares a la variante 1 de Israel y a los serotipos 4/91); y 4) que la cepa variante 2 de Israel que se encontró circulando en Turquía parecía que estaba experimentando evolución molecular. En conclusión, cepas del virus de la bronquitis infecciosa que fueron genéticamente diferentes, con base en la secuencia parcial del gene S1 y que incluyeron cepas similares a vacunas, se encontraron circulando en pollos de engorde y en gallinas de postura en Turquía y la cepa variante 2 de Israel se encontró experimentando evolución.

Key words: avian coronavirus, AvCoV, IBV, S1 sequence, phylogenetic, chicken

Abbreviations: AvCoV-IBV = avian coronavirus-infectious bronchitis virus; $\mathrm{cDNA}=$ complementary DNA; IB = infectious bronchitis; IBV = infectious bronchitis virus; $\mathrm{MEM}=$ minimal essential medium; RT-PCR = reverse transcriptase-polymerase chain reaction; $\mathrm{S} 1=$ Spike-1; SPF = specific-pathogen-free

\footnotetext{
${ }^{\mathrm{H}}$ Correpsonding author. E-mail: hyilmaz@istanbul.edu.tr
}

Infectious bronchitis virus (IBV) is an important pathogen of chickens, threatening the poultry industry worldwide. It is the causal agent of infectious bronchitis (IB), an acute and highly contagious disease. Vaccines are available, but genetic variation and the lack of 
cross-protection between different viral genotypes make the control of infections difficult $(6,7,12,22)$. Therefore it is important to genetically characterize circulating strains of IBV to guide national or regional strategies for combating IB by designing appropriate diagnostics and vaccination regimes.

Avian coronavirus-infectious bronchitis virus (AvCoV-IBV) is an enveloped, single-stranded RNA virus, belonging to the genus Gammacoronavirus within the family of Coronaviridae and the order Nidovirales. It has a 27 to $28 \mathrm{~kb}$ genome encoding four structural proteins, spike $(S)$, membrane $(M)$, envelope $(E)$, and nucleocapsid (N) (6). Genetic differences affecting antigenicity and immunogenicity are mainly restricted to the $S$ protein. This is composed of two subunits Spike-1 (S1) and -2, of which S1 is more variable. Genetic variation, caused by mutations in the IBV $S 1$ sequence, is responsible for the worldwide diversity of IBV isolates $(9,16,21,27)$.

The 793/B, Massachusetts, QX, and IT-02, serotypes have been frequently reported (28) as circulating in Europe. However, different strains of IBV have been circulating in the Middle East. For example, IBV variants like Q1 (CK/CH/LDL97I/97) $(1,11,14,17,20,26,27)$, IBV variant-1 (793/B, IS/222/96, IS/251/ 96, and IS/64714/96), IBV variant-2 (IS/223/96, IS/572/98, IS/ 585/98, and IS/589/98), Egypt/Beni-Seuf/01, Sul/01/09, D274, and IS/885/00 as well as vaccine strains derived from Massachusetts and 4/91, $(8,18,19,24,25)$ have been detected.

In Turkey, vaccine strains like Ma5, H120, 4/91 and Israeli variant- 2 have been detected (15). IBV vaccines containing Ma5, 4/ 91, H120, Israel variant-2, and a combination of H120-D274 strains were used in broilers and H120, M41, and 4/91 in layers to control virulent IB strains in Turkey. Despite the presence and application of IBV vaccines in poultry, the emergence of new AvCoV-IBV variants can threaten poultry health and production all over the world. Therefore it is important to genetically characterize circulating strains of AvCoV-IBV. This study was carried to investigate $S 1$ gene variation and pathologic lesions caused by AvCoV-IBV in Turkey.

\section{MATERIALS AND METHODS}

Study population. Forty-nine commercial broiler and 14 layer flocks were selected from four geographic regions of Turkey, (Marmara, western Black Sea, the Mediterranean, and Inner Anatolia), between January 2013 and June 2015. Flocks were selected by veterinarians using the following criteria: flocks showing clinical signs of respiratory disease and flocks from the same vicinity that did not show clinical signs of respiratory disease. Flocks had been previously vaccinated against IBV except two flocks without vaccination. IBV vaccines Ma5, 4/91, H120, or Israel variant- 2 were used in broilers, and 4/91 in layers analyzed in this study (Table 1).

Sample collection. Layers. Four or five chickens either with or without respiratory signs were selected from each layer flock and tracheal swabs taken from these chickens. Broilers: Five 20-to-35-day-old birds either with or without clinical signs of respiratory disease were selected. The clinical signs were recorded, and they were then humanely sacrificed, autopsied, and pathologic findings recorded. Tissue samples from trachea, lung, kidneys, proventriculus, and intestine including caecal tonsils were taken for virologic and histologic analysis. Samples for histologic examination were fixed in $10 \%$ neutral buffered formalin embedded in paraffin blocks and 4-5 $\mu \mathrm{m}$ sections cut, stained with hematoxylin and eosin, and examined by light microscopy.

RNA extraction and reverse transcription. Total RNA was extracted from tissues and allantoic fluid of inoculated eggs using
RNeasy and QIAamp Viral RNA mini kits, respectively, as described by the manufacturer (Qiagen, Turkey). The amount of RNA, in $50 \mu \mathrm{l}$ of extracted sample, was determined using a NanoDrop spectrophotometer (NanoDrop 1000c, Thermo Scientific, Waltham, MA). Reverse transcription and generation of complementary DNA (cDNA) was performed in two steps as described previously (31).

Detection of AvCoV-IBV by TaqMan real-time RT-PCR assay. The TaqMan real-time RT-PCR used in this study was a modification of the method described previously (4). The primers and probe specific for IBV are given in Table 2. A standardized TaqMan real-time RTPCR reaction consisted of a total volume of $25 \mu \mathrm{l}$ reaction mixture containing of $12.5 \mu \mathrm{l} \mathrm{GoTaq}{ }^{\circledR}$ Colorless Master Mix (Promega), $1 \mu \mathrm{l}$ IBV5-GU391 primer $(5 \mathrm{pMol} / \mu \mathrm{l}), 1 \mu \mathrm{l}$ IBV5-GL533 primer $(5 \mathrm{pMol} /$ $\mu \mathrm{l}), 0.2 \mu \mathrm{l}$ IBV5-G probe $(5 \mathrm{pMol} / \mu \mathrm{l}), 5.3 \mu \mathrm{l}$ nuclease-free water, and 5 $\mu \mathrm{l}$ cDNA. The mixture was placed in a thermal cycler (Biorad, Chromo4) and the polymerase activated, by incubation at $95 \mathrm{C}$ for $2 \mathrm{~min}$. Cycling conditions were $94 \mathrm{C}$ for $1 \mathrm{~s}$ and $60 \mathrm{C}$ for $60 \mathrm{~s}$ over 40 cycles. Negative controls included DNA extracted from samples that were negative for $\mathrm{AvCoV}-\mathrm{IBV}$ and nuclease-free water in place of template. A positive control consisted of RNA from the trachea of a chicken previously infected with IBV. The chicken GPADH (glyceraldehyde-3phosphate dehydrogenase) gene was used as an internal control for the presence of RNA.

Virus isolation. Tissue samples (trachea, lung, or kidney) and tracheal swabs that were positive for AvCoV-IBV, by TaqMan real-time RT-PCR with a $C_{T}$ value of $<25$ were subjected to virus isolation using the conventional method of inoculating embryonated eggs. Briefly, $5 \mathrm{~g}$ of lung, trachea, or kidney samples were homogenized in Glasgow minimal essential medium (Biochrom, Turkey) containing 5\% antibiotic-antimycotic solution, filtered using a $0.22 \mu \mathrm{m}$ Millipore filter and the filtrates used to inoculate the chorioallantoic cavity of groups of four 9- or 10-day-old specific-pathogen-free (SPF) embryonated hens' eggs (Veterinary Control Institute, Bornova, Izmir, Turkey). Eggs were observed every other day, over 7 days, for the presence of embryo death, vascularization and dwarfism. After 7 days RNA was isolated from the allantoic fluid and analyzed by TaqMan real-time RTPCR for the presence of AvCoV-IBV RNA as described above. If samples were negative on the first passage, second and third passages were performed.

Partial S1 gene sequencing. The cDNA of IBV generated from samples found positive by TaqMan real-time RT-PCR were subjected to sequencing by using the primers given in Table 2. The IBV S1 sequences, generated from 29 samples derived from broiler flocks positive for AvCoV-IBV and 7 samples derived from layer flocks positive for AvCoV-IBV, were partially sequenced. The partial S1 sequences consisted of (1) a 393 bp PCR product from nucleotide positions 705 to 1097 in the IBV S1 sequence produced by nested PCR as described previously (29) and (2) a $462 \mathrm{bp}$ PCR product from nucleotide positions 1082 to 1545 in the IBV S1 sequence. To amplify 462 bp region of S1 gene, a standardized in house RT-PCR reaction consisted of a total volume of $25 \mu \mathrm{l}$ reaction mixture containing $0.5 \mu \mathrm{l}$ $(1 \mu \mathrm{M})$ of forward (IBV FOR3) and reverse primers (IBV REV3), 12,5 $\mu \mathrm{l} \mathrm{GoTaq}{ }^{\circledR}$ Colorless Master Mix (Promega), $6.5 \mu$ l nuclease-free water, and $5 \mu \mathrm{l}$ of cDNA. The mixture was placed in a thermal cycler (Biorad, Chromo-4), and the polymerase was then activated by incubation at 94 $\mathrm{C}$ for $15 \mathrm{~min}$. Cycling conditions were $94 \mathrm{C}$ for $30 \mathrm{sec}, 50 \mathrm{C}$ for $1 \mathrm{~min}$, and $68 \mathrm{C}$ for $1 \mathrm{~min}$ for 40 cycles. Nuclease-free water was used as negative control in place of template.

Phylogenetic analyses. The reference sequence set for IBV classification obtained from Valastro and others (30) was used to reconstruct the topology of the $S 1$ sequences generated in this study. The phylogenetic tree was inferred using the ML method available in PhyML 3.0 (10) incorporating a GTR model of nucleotide substitution with a gamma distribution of among-site rate variation (with four rate categories, $\Gamma 4$ ) and a SPR branch-swapping search procedure. Prior to 
Table 1. Results analyzed in the study. ${ }^{\mathrm{A}}$

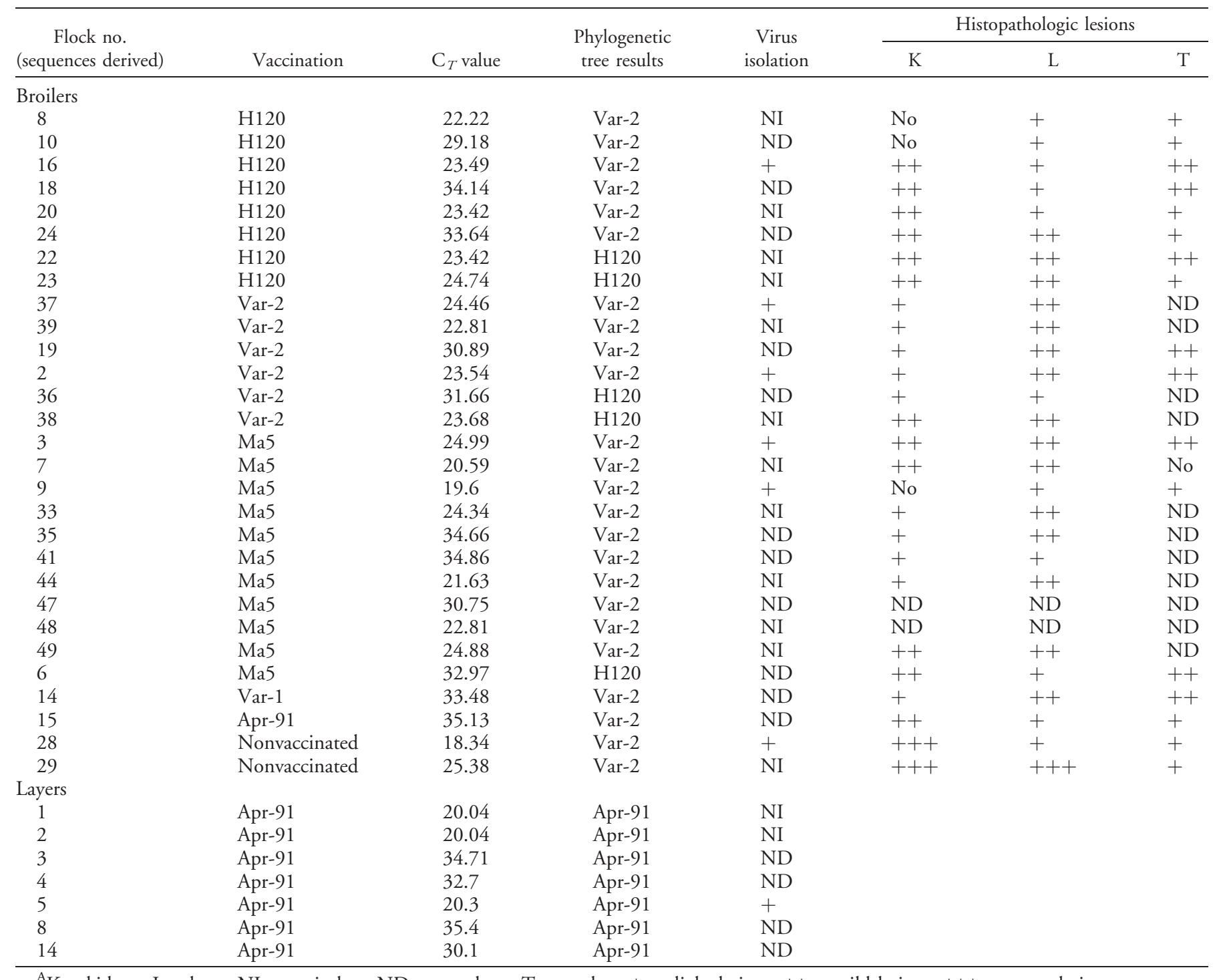

${ }^{\mathrm{A}} \mathrm{K}=$ kidney; $\mathrm{L}=$ lung; $\mathrm{NI}=$ no isolate; $\mathrm{ND}=$ not done; $\mathrm{T}=$ trachea; $+=$ slight lesions; $++=$ mild lesions; $++=$ severe lesions.

phylogenetic analysis, all hypervariable and potentially poorly aligned regions were removed using the Gblocks program (http://molevol. cmima.csic.es/castresana/Gblocks.html) (5) as previously described by Valastro and others (30). Nodal supports in the PhyML analysis were assessed using Shimodaira-Hasegawa-like branch supports (10). The GenBank accession numbers of some positive samples detected in this study are KT021472, KT021473, KT021474, KT021475, KT021476, KT021477, KT021478, and KT021479.

Table 2. Primers and probes used in the study.

\begin{tabular}{|c|c|c|c|c|c|}
\hline Primers & Sequences $5^{\prime}-3^{\prime}$ & $\begin{array}{l}\text { Product } \\
\text { size (bp) }\end{array}$ & $\begin{array}{l}\text { Target } \\
\text { region }\end{array}$ & Location & Reference \\
\hline IBV5-GU391 & GCTTTTGAGCCT AGCGTT & 142 & 5'-UTR & $391-408^{\mathrm{A}}$ & Callison et al. 2006 (4) \\
\hline IBV5-GL533 & GCCA TGTTGTCACTGTCT A TTG & & & $533-512$ & \\
\hline SX1 & CACCTAGAGGTTTGT/CTA/T GCAT & 393 & S1 gene & $677-698^{\text {B }}$ & Worthington et al. 2008 (29) \\
\hline SX2 & ТCСАССТСТАТАAАСАCС C/T ТT & & & $1148-1168$ & \\
\hline SX3 & TAATACTGG C/T AATTTTTCAGA & & & $705-725$ & \\
\hline IBV-REV3 & CTAAAAGTAAGAATGCCAAC & & & $1525-1545$ & \\
\hline
\end{tabular}

\footnotetext{
${ }^{A}$ GenBank accession number AY851295.

${ }^{\mathrm{B}}$ GenBank accession number Z83979.

${ }^{\mathrm{C}}$ GenBank accession number KJ524614.
} 


\section{RESULTS}

Clinical, necropsy, and histopathologic findings. Mortality rates in clinically affected broiler flocks ranged from $4 \%$ to $9 \%$. The clinical signs observed in these flocks (Table 1: Flock 2, Flock 23, Flock 24, Flock 28 nonvaccinated, Flock 29 nonvaccinated) ranged from depression, ruffled feathers, poor growth, nasal discharge, rales, and diarrhea. In contrast, only respiratory signs were observed in two layer flocks.

At necropsy, the common lesions observed included congestion and petechial hemorrhages in the trachea and additionally edema, airsacculitis, and serous or seropurulent exudate in the lungs. Congestion, hemorrhages, and erosions were observed in the digestive tract. No gross lesions were observed in the kidneys.

Histopathologic examination of the trachea identified loss of cilia, degeneration and necrosis of epithelial cells, hyperemia and/or edema in the mucosa and submucosa, and infiltration of heterophils. Epithelial cell degeneration, necrosis, hyperemia and heterophil, lymphocyte and macrophage infiltration with edema, and increase in mucus were also observed in the lung. Hyperemia and inflammatory lesions as described above including an obstructed lumen of air capillaries were also seen in para-bronchial tissue. Hyperemia and granular-vacuolar degeneration were seen in the tubular epithelial cells of the kidney of some chickens including focal mononuclear cell infiltration.

TaqMan real-time RT-PCR for AvCoV-IBV. For RT-PCR a $\mathrm{C}_{T}$ value of 35 or less is considered to be positive for the presence of AvCoV-IBV RNA. AvCoV-IBV RNA was detected in 64.2\% (9/14) of layer flocks and 83.6\% (41/49) of broiler flocks.

On further analysis, AvCoV-IBV RNA was detected in 27 out of $30(90 \%)$ tracheal samples, 31 out of $49(62.2 \%)$ lung samples, 7 out of $22(31.8 \%)$ caecal tonsils, and 4 out of 49 (8.1\%) kidney samples. Clinical signs and severe pathologic lesions (gross) were observed in the organs of birds that scored a $C_{T}$ value of less than 25 . No $\mathrm{C}_{T}$ values were obtained from $\mathrm{AvCoV}$-IBV RNA-negative test samples or negative controls.

Virus isolation. AvCoV-IBV was isolated from tracheal tissues collected from six broiler flocks and from tracheal swabs taken from one layer flock after 7 days of incubation after one passage in embryonated SPF hens' eggs (Table 1). No AvCoV-IBV detection was achieved after second or third passages of the other samples cultured. Dwarfing and hemorrhage of the embryo was observed in eggs inoculated with AvCoV-IBV RT-PCR-positive inoculum. No lesions were observed in the control eggs.

Analysis of the partial IBV S1 sequences. Analysis of the partial S1 sequences derived from some of the broiler samples identified that $17.2 \%$ of the sequences were closely related $(95.6 \%-99.2 \%)$ to the S1 sequences of IBV Ma5 and 5/49 H120 vaccine strains (GI-1), and $24 / 49(48.9 \%)$ of those were similar $(94.8 \%-99.4 \%)$ to the Israel variant-2 (GI-23) (Table 1; Fig. 1). In contrast, all of the partial S1 sequences obtained from the layer flock samples were found to be identical to the IBV 4/91 vaccine strain (GI-13) (Table 1; Fig. 1).

The partial S1 sequences of the AvCoV-IBVs detected in five of the broiler flocks were similar to AvCoV-IBV strains, Ma5, M41 (AY561711), and H120 (FJ888351) (Fig. 1). In addition, the partial S1 sequences of the AvCoV-IBVs detected in 24 of the broiler flocks were similar to IBV Israel variant-2 (EU780077, JX027070, and JX173488) (Fig. 1) and an AvCoV-IBV previously identified and reported in Turkey (HM802259). Additionally, the Israeli variant-2 detected in this study clustered phylogenetically with the Turkish IBV strain, chicken/Turkey/10RS-3161/2010, but aligned in a different subcluster. The partial S1 sequences of AvCoV-IBVs detected in seven of the layer flocks were different from those found in broiler flocks but more similar to AvCoV-IBV strains previously reported from Iran, India, and China. However, they showed some similarity to Israel variant-1 and 4/91 strains of IBV (Fig. 1).

The AvCoV-IBV identified in this study as having a partial S1 sequence to that of IBV Israel variant- 2 also showed similarity to AvCoV-IBVs Egypt/Beni-Suef/01 (97.8\%-99.4\%), IS/1494/06 (98.7\%-99.7\%), IB variant-2 (94.8\%-96.7\%), and chicken/Turkey/10RS-3161/2010 (96.2\%-98.1) but with different isolates IS/ 885/00 (80.1\%-90.1\%), IS/ 720/99 (79.3\%-88.9\%), Sul/01/09 (79.6\%-87.8\%), and CK/CH/LDL/97I (78.6-83.0\%); the last two have been detected in the Middle East.

Analysis of the partial S1 sequences of AvCoV-IBVs detected in seven of the layer flocks examined were found to be similar to IBV 4/ 91 using the in-house designed primers (IBV-FOR3 and IBVREV3; Table 1). The sequences of five of the samples were also amplified and confirmed using other primers (29).

\section{DISCUSSION}

Variants of AvCoV-IBV have been detected in different countries and are having an economic impact on poultry production globally (7). Antigenic variation, resulting in decreased level of crossprotection between different strains, is a major obstacle for the development of an efficacious vaccine. In this study, the AvCoV IBV was detected in $83.6 \%$ and $64.2 \%$ of the broiler and layer flocks assessed, respectively. Amongst the IBV strains identified in the broiler flocks, $17.2 \%$ represented the detection of the IBV Ma5 and H120 vaccine strains $(95.6 \%-99.2 \%)$ and $48.9 \%$ represented the Israel variant 2 isolate (94.8\%-99.4\%), whereas all of the layer flock-derived sequences were represented in the 4/91 vaccine strain (96.2\%-99.5\%). Results from field surveys for assessing the presence of IBV in chickens in Western Europe showed 59\% positive for AvCoV-IBV with about $50 \%$ of the positive samples representing identification of vaccine strains (29). Similarly, vaccine strains were also detected following the assessment of poultry in the Middle East for the presence of IBV $(13,19,25)$. Furthermore, in this study, IBV Israel variant -2 in addition to vaccine strains H120, Ma5, and 4/91 was detected in some flocks that had been vaccinated. Overall these results demonstrate the existence of different genotypes of IBV affecting poultry, and in Turkey, in particular, it suggests the copersistence of IBV vaccine as well as field isolates in poultry flocks, which could favor the emergence of new virulent virus variants and escape mutants.

The phylogenetic comparison of the partial S1 sequences derived from some of the samples in this study showed that 24 of the sequences from broiler flocks were closely related to IBV Israel variant-2 isolates, IS/1494/06, IB VAR2, chicken/Turkey/10RS3161/2010, and Egypt/Beni-Suef/01, but different from IBV vaccine strains, H120, Ma5, and 4/91, currently applied to poultry flocks in Turkey. The sequences identified in this study were also different from IBV QX and Italy-02 isolates found in other European countries. In addition, five sequences were found to be similar to Ma5, H120, and M41, whereas seven sequences were similar to the $4 / 91$ vaccine strain. The Israeli variant- 2 detected in this study was found to be similar to strain chicken/Turkey/10RS- 


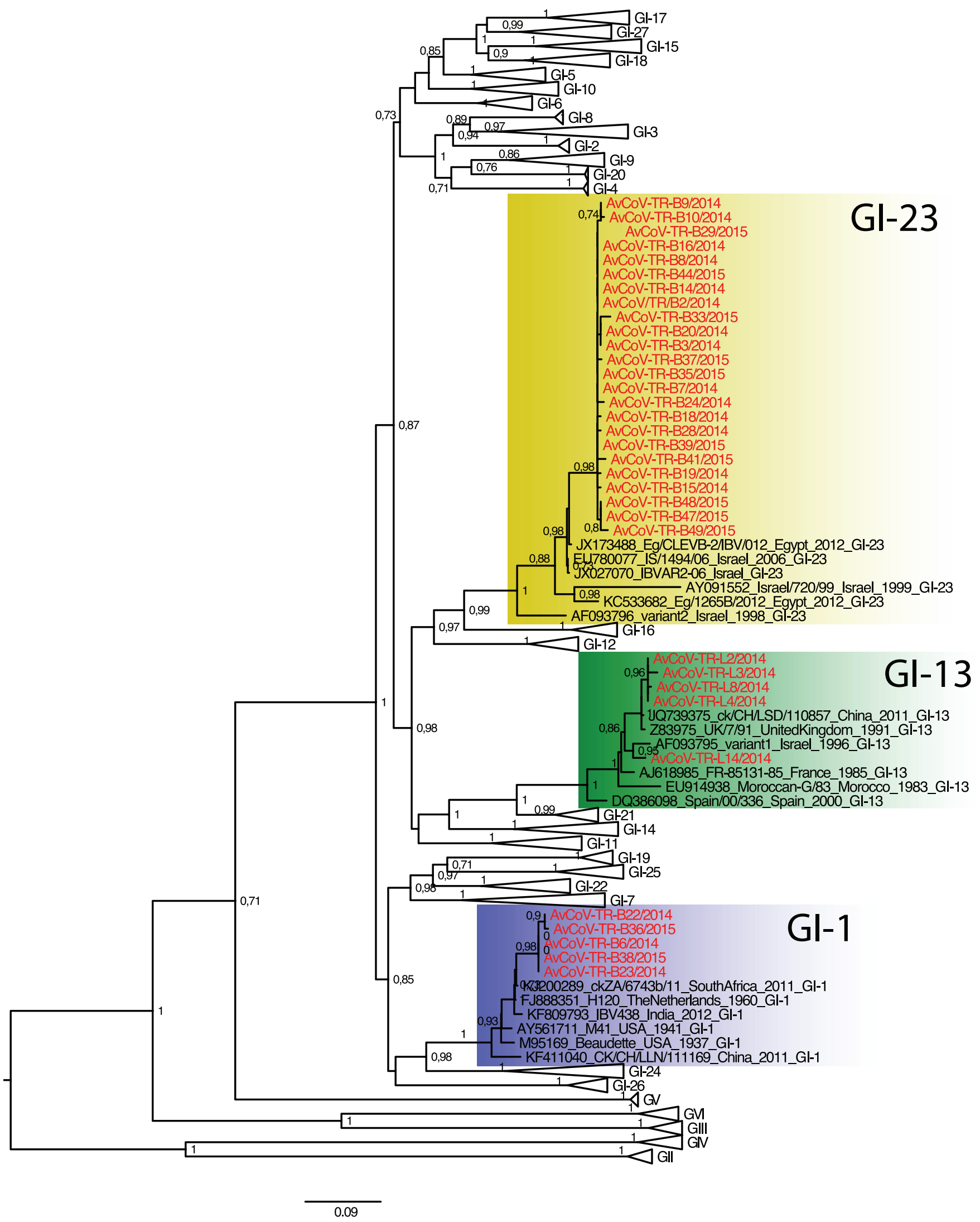

Fig. 1. Maximum likelihood phylogenetic tree of the S1 nucleotide sequences. Viruses sequenced in this study are colored in red. SH-like branch supports are shown for key nodes. 
$3161 / 2010$, previously reported in Turkey; although these isolates clustered in the same clade, they aligned in a different subcluster. This observation suggests that the Israeli variant- 2 circulating in Turkey is diverging. In Turkey, chickens are routinely vaccinated with multiple IBV vaccines, representing heterogeneous serotypes, including the recent introduction of the vaccine strains 4/91 and Israel variant-2 to control virulent IBV in poultry. The presence of these recently introduced vaccine strains were identified by samples taken from poultry flocks as part of this study.

Turkey has a large and increasing poultry production industry and serves as a bridge between Europe and Asia with eight neighboring poultry-producing countries $(1,3,19,23,25)$. The AvCoV-IBV isolates detected in this study were found to be similar to IBV isolates detected in Israel, Turkey, Iraq, Jordan, and Egypt like strains KF179074, HM802259, EU780077, JX027070, JX173488, and KF153245, but different from IBV isolates QX and Italy-02 (EU780077) $(1,15,23,29)$, detected in other European countries. The predominance of IBV genotypes representing isolates belonging to Asian-type lineages, found in this study, suggests that Turkey has more cross-border poultry trade with Middle Eastern countries than with European countries.

The pathologic lesions associated with AvCoV-IBVs in Turkey have not been investigated previously. The predominant histopathologic and necropsy findings observed in this study included hemorrhages and congestions in the trachea and congestion of the lungs, which are consistent with previous findings reported from the field (27) and from experimental infections (2). Kidneys were affected only in a few birds that were not vaccinated and were positive for Israeli variant-2. QX-like AvCoV-IBVs as well as strains found in Israel and northern Iraq are known to induce or be associated with kidney disease $(2,18,19)$; our results, from both clinical and sequence analysis, suggests that these types of IBVs are rarely present in Turkish poultry flocks.

It should be noted that the flocks investigated in this study were reportedly vaccinated against IBV. Interestingly, mild respiratory signs were seen in some vaccinated flocks. The detection of AvCoVIBV-associated disease in these flocks suggests that either 1) the current IBV vaccines are not efficacious for protection against some of the circulating strains identified in this study; 2) the vaccination regimen applied was inadequate to provide protection; or 3) chickens are exposed to other respiratory pathogens by stress during vaccination, which decreases immunity. These speculations need to be determined in future studies.

In conclusion, AvCoV-IBVs similar to those circulating in various countries in the Middle East were identified in chickens from Turkish broiler and layer flocks. Pathologic changes were mainly detected in the respiratory tract of infected chickens. The results indicate that Israeli variant-2 circulating in Turkey is undergoing evolution. The efficacy of the vaccines currently used in Turkey against some of the circulating AvCoV-IBVs should be assessed in future studies.

\section{REFERENCES}

1. Ababneh, M., A. E. Dalab, S. Alsaad, and M. Al-Zghoul. Presence of infectious bronchitis virus strain $\mathrm{CK} / \mathrm{CH} / \mathrm{LDL} / 97 \mathrm{I}$ in the Middle East. ISRN Vet. Sci., Article ID 201721. 2012.

2. Benyeda, Z., L. Szeredi, T. Mató, T. Süveges, G. Balka, Z. AbonyiTóth, M. Rusvai, and V. Palya. Comparative histopathology and immunohistochemistry of QX-like, Massachusetts and 793/B serotypes of infectious bronchitis virus infection in chickens. J. Comp. Pathol. 143:276283. 2010 .

3. Callison, S. A., D. A. Hilt, T. O. Boynton, B. F. Sample, R. Robison, D. E. Swayne, and M. W. Jackwood. Development and evaluation of a real-time Taqman RT-PCR assay for the detection of infectious bronchitis virus from infected chickens. J. Virol. Methods 138:60-65. 2006.

4. Callison, S. A., M. W. Jackwood, and D. A. Hilt. Molecular characterization of infectious bronchitis virus isolates foreign to the United States and comparison with United States isolates. Avian Dis. 45:492-499. 2001.

5. Castresana, J. Selection of conserved blocks from multiple alignments for their use in phylogenetic analysis. Mol. Biol. Evol. 17:540-552. 2000.

6. Cavanagh, D. Coronavirus avian infectious bronchitis virus. Vet. Res. 38:281-297. 2007.

7. De Wit, J. J., J. K. Cook, and H. M. van der Heijden. Infectious bronchitis virus variants: a review of the history, current situation and control measures. Avian Pathol. 40:223-235. 2011.

8. Gelb, J., Jr., Y. Weisman, B. S. Ladman, and R. Meir. S1 gene characteristics and efficacy of vaccination against infectious bronchitis virus field isolates from the United States and Israel (1996 to 2000). Avian Pathol. 34:194-203. 2005.

9. Gough, R. E., C. J. Randall, M. Dagless, D. J. Alexander, W. J. Cox, and D. Pearson. A new strain of infectious bronchitis virus infecting domestic fowl in Great Britain. Vet. Rec. 130:493-494. 1992.

10. Guindon, J., F. Dufayard, V. Lefort, M. Anisimova, W. Hordijk, and O. Gascuel. New algorithms and methods to estimate maximumlikelihood phylogenies: assessing the performance of PhyML 3.0. Syst. Biol. 59:307-321. 2010.

11. Han, Z., C. Sun, B. Yan, X. Zhang, Y. Wang, C. Li, Q. Zhang, Y. Ma, Y. Shao, Q. Liu, X. Kong, and S. Liu. A 15-year analysis of molecular epidemiology of avian infectious bronchitis coronavirus in China. Infect. Genet. Evol. 11:190-200. 2011.

12. Jackwood, M. W. Review of infectious bronchitis virus around the world. Avian Dis. 56:634-641. 2012.

13. Jahantigh, M., S. Salari, and M. Hedayati. Detection of infectious bronchitis virus serotypes by reverse transcription polymerase chain reaction in broiler chickens. SpringerPlus 2:36-39. 2013.

14. Ji, J., J. Xie, F. Chen, D. Shu, K. Zuo, C. Xue, J. Qin, H. Li, Y. Bi, J. Ma, and Q. Xie. Phylogenetic distribution and predominant genotype of the avian infectious bronchitis virus in China during 2008-2009. Virol. J. 8:184-192. 2011.

15. Kahya, S., F. Coven, S. Temell1, A. Eyıgor, and K. T. Carlı. Presence of IS/1494/06 genotype-related infectious bronchitis virus in breeder and broiler flocks in Turkey. Ankara Univ. Vet. Fac. J. 60:27-31. 2013.

16. Le Gros, F. X. Serotyping studies on recent IBV isolates from France and various regions of the world. In: Proceedings of the International Symposium on Infectious Bronchitis and Pneumovirus Infections in Poultry, E. F. Kaleta and U. Heffels-Redmann, eds. Rauischholzhausen, Germany. pp. 205-209. 1998.

17. Ma, H., Y. Shao, C. Sun, Z. Sun, X. Liu, H. Guo, X. Liu, X. Kong, and S. Liu. Genetic diversity of avian infectious bronchitis coronavirus in recent years in China. Avian Dis. 56:15-28. 2012.

18. Mahmood, Z. H., R. R. Sleman, and A. U. Uthman. Isolation and molecular characterization of Sul/01/09 avian infectious bronchitis virus, indicates the emergence of a new genotype in the Middle East. Vet. Microbiol. 150:21-27. 2011.

19. Meir, R., E. Rosenblut, S. Perl, N. Kass, G. Ayali, S. Perk, and E. Hemsani. Identification of a novel nephropathogenic infectious bronchitis virus in Israel. Avian Dis. 48:635-641. 2004.

20. Ovchinnikova, E. V., Y. A. Bochkov, L. O. Shcherbakova, Z. B. Nikonova, N. G. Zinyakov, N. P. Elatkin, N. S. Mudrak, A.V. Borisov, and V. V. Drygin. Molecular characterization of infectious bronchitis virus isolates from Russia and neighbouring countries: identification of intertypic recombination in the S1 gene. Avian Pathol. 40:507-514. 2011.

21. Parsons, D., M. M. Ellis, D. Cavanagh, and J. K. A. Cook. Characterisation of an avian infectious bronchitis virus isolated from IBvaccinated broiler breeder flocks. Vet. Rec. 131:408-411. 1992. 
22. Roh, H. J., D. A. Hilt, and M. W. Jackwood. Simultaneous detection of five major serotypes of avian coronavirus by a multiplex microsphere-based assay. J. Vet. Diagn. Invest. 25:458-466. 2013.

23. Roussan, D. A., G. Y. Khawaldeh, and I. A. Shaheen. Infectious bronchitis virus in Jordanian chickens: seroprevalence and detection. Can. Vet. J. 50:77-80. 2009.

24. Roussan, D. A., W. S. Totanji, and G. Y. Khawaldeh. Molecular subtype of infectious bronchitis virus in broiler flocks in Jordan. Poult. Sci. 87:661-664. 2008.

25. S. A. Shapouri, M. R., M. Mayahi, K. Assasi, and S. Charkhkar. A survey of the prevalence of infectious bronchitis virus type 4/91 in Iran. Acta Vet. Hung. 52:163-166. 2004.

26. Toffan, A., M. Bonci, L. Bano, V. Valastro, M. Vascellari, I. Capua, and C. Terregino. Diagnostic and clinical observation on the infectious bronchitis virus strain Q1 in Italy. Vet. Ital. 49:347-355. 2013.

27. Toffan, A., C. Terregino, E. Mazzacan, I. Castaldello, I. Capua, and M. Bonci. Detection of Chinese Q1 strain of infectious bronchitis virus in Europe. Vet. Rec. 169:212-213. 2011.

28. Tosi, G., R. Taddei, I. Barbieri, L. Fiorentini, and P. Massi. Caratterizzazione molecolare dei ceppi di virus della bronchite infettiva aviare isolati in Italia nel periodo 2007-2009 e nel primo bimestre del 2010. In: Proceedings of the 49th Annual Conference of Acts Italian Society of Avian Pathology(SIPA), Forli, Italy. pp. 217. 2010.
29. Worthington, K. J., R. J. Currie, and R. C. Jones. A reverse transcriptase-polymerase chain reaction survey of infectious bronchitis virus genotypes in Western Europe from 2002 to 2006. Avian Pathol. 37:247257. 2008.

30. Valastro, V., E. C. Holmes, P. Britton, A. Fusaro, M. W. Jackwood, G. Cattoli, and I. Monne. S1 gene-based phylogeny of infectious bronchitis virus: an attempt to harmonize virus classification. Infect. Genet. Evol. 39:349-364. 2016.

31. Yilmaz, H., N. Turan, E. Altan, K. Bostan, A. Yilmaz, C. R. Helps, and K. O. Cho. First report on the phylogeny of bovine norovirus in Turkey. Arch. Virol. 1561:143-147. 2011.

\section{ACKNOWLEDGMENTS}

We declare no conflicts of interest. All applicable international, national, and/or institutional guidelines for the care and use of animals were followed. Approval was taken from the Ethical Committee of the University of Istanbul. This study was funded by the Turkish Scientific and Technical Research Foundation (TUBITAK-Project No. 113O411). 